\title{
Hubungan Karakteristik Sosial Ekonomi Petani Padi Dengan Tingkat Adopsi Inovasi Sistem Tanam Hazton Di Desa Malalin Kabupaten Enrekang
}

\section{Relationship of rice farmers social economic characteristics With the adoption innovation of hazton plant system Malalin village, enrekang district}

\author{
Khaeriyah Darwis \\ Program Studi Agribisnis, Universitas Muhammadiyah Makassar \\ Jl. Sultan Alauddin no.259 Kota Makassar 90222 \\ *Corresponding author : khaeriyah.darwis@unismuh.ac.id
}

Diterima tanggal 08 Mei 2020, Disetujui tanggal 30 Mei 2020

\begin{abstract}
Abstrak
Penelitian ini bertujuan untuk menganalisis hubungan karakteristik sosial ekonomi petani dengan tingkat adopsi inovasi sistem tanam hazton, dan sikap petani terhadap usahatani padi sawah sistem tanam hazton. Metode pengambilan sampel dengan cara sistematis (systematic sampling) dengan 26 orang responden petani padi di Desa Malalin Kabupaten Enrekang. Metode analisis data adalah Korelasi Rank Spearman, teknik penskalaan likert dan deskriptif. Hasil penelitian menunjukkan karakteristik sosial ekonomi petani yang berpengaruh signifikan terhadap tingkat adopsi inovasi sistem tanam hazton adalah luas lahan dan pendapatan. Sedangkan karakteristik sosial ekonomi petani yang berpengaruh non signifikan terhadap tingkat adopsi inovasi sistem tanam hazton adalah umur, lamanya berusahatani, pendidikan dan jumlah tanggungan keluarga. luas lahan, pendidikan, jumlah tanggungan keluarga dan pendapatan bernilai positif ( $R s+$ ) dan memiliki hubungan yang searah dengan tingkat adopsi inovasi sistem tanam hazton. Sedangkan umur dan pengalaman berusahatani bernilai negatif (Rs -) dan memiliki hubungan yang tidak searah dengan adopsi inovasi sistem tanam hazton. Petani sampel sebanyak $53,84 \%$ bersikap negatif dan $46,16 \%$ bersikap positif terhadap penerapan usahatani padi sawah dengan sistem tanam hazton. Dapat disimpulkan bahwa respon dan sikap petani terhadap adopsi inovasi belum seluruhnya menerima dilihat dari hasil presentase penilaian persepsi petani. Namun dari hasil perhitungan pendapatan usahatani petani padi yang menggunakan sistem tanam hazton menunjukkan keuntungan yang didapatkan petani dibanding menggunakan sistem tradisional. Diharapkan kedepannya dengan tingkat keuntungan yang didapatkan petani yang menggunakan sistem tanam hazton dapat menjadi motivasi petani tradisional untuk mengadopsi sistem tanam hazton.
\end{abstract}

Kata Kunci : Hazton, Malalin, Petani Padi, Sistem Tanam

\begin{abstract}
This study aims to analyze the relationship between socio-economic characteristics of farmers with the level of adoption of the Hazton planting system innovation, analyze the attitudes of farmers towards the hazton farming system. The method of sampling was systematically (systematic sampling) with 26 respondents of rice farmers in Malalin Village, Enrekang Regency. Data analysis methods are Spearman Rank Correlation, Likert and descriptive scaling techniques. The results showed that socio-economic characteristics of farmers that had a significant effect on the adoption rate of Hazton's cropping system innovations were land area and income. While the socio-economic characteristics of farmers that have a nonsignificant effect on the level of adoption of hazton cropping system innovations are age, farming experience, education and number of family dependents. Land area, education, number of family dependents and positive value of income $(R s+)$ and have a direct relationship with the level of adoption of hazton cropping system innovation. While the age and experience
\end{abstract}


of farming is negative (Rs -) and has a unrelated relationship with the adoption of the Hazton planting system innovation. As many as $53.84 \%$ of sample farmers were negative and $46.16 \%$ were positive towards the adoption of lowland rice farming using the Hazton planting system. It can be concluded that the responses and attitudes of farmers to the adoption of innovations have not been fully accepted as seen from the results of the percentage assessment of farmers' perceptions. However, the results of the calculation of farm income for rice farmers who use the hazton planting system show the benefits that farmers get compared to using the traditional system. It is hoped that in the future, the level of profit obtained by farmers who use the hazton planting system can motivate traditional farmers to adopt the hazton planting system.

Keyword : Hazton, Malalin, Rice Farmer, Planting System

\section{PENDAHULUAN}

Desa Malalin merupakan desa yang berada di Kecamatan Cendana yang merupakan sentral penghasil gabah, dimana pada tahun 2014 mengalami peningkatan mencapai 5,025 Ton yang di panen dengan luas lahan $556 \mathrm{Ha}$. Bila dibandingkan dari tahun ke tahun mengalami penurunan. Dimana tahun 2017 tidak ada sama sekali produktivitas yang dihasilkan. Upaya dari penyuluh pertanian untuk mensosialisasikan sistem tanam hazton masih terus digalakkan mengingat masih banyak petani di Desa Malalin yang mempertahankan sistem tanam hambur benih langsung dibanding mengadopsi sistem tanam yang baru baik jajar legowo maupun hazton.Teknologi Hazton dapat diartikan sebagai cara bertanam padi dengan menggunakan bibit tua yang berumur 25-35 hari setelah semai dengan jumlah bibit padat yaitu $20-30$ bibit per lubang tanam.

Hasil penelitian Ekaria (2019) Ratarata produksi usahatani padi sawah dengan metode hazton di Desa Lolori Kabupaten Halmahera yaitu 6,165 ton/ha/musim tanam dengan rata-rata pendapatan Rp. 29.256.175/ha/musim tanam serta nilai R/C Ratio yaitu 2,79 atau nilai $R / C$ adalah $>1$ sehingga usahatani padi sawah dengan metode hazton layak diusahakan karena sangat menguntungkan. Perlunya sosialisasi dari Dinas Pertanian Kabupaten Halmahera Barat tentang usahatani padi sawah dengan metode hazton serta penanganan hama penyakit yang dapat diterapkan oleh petani, dengan angka produktivitas padi serta nilai $\mathrm{R} / \mathrm{C}$ ratio yang tinggi, pemerintah dapat menjadikan Teknologi Hazton sebagai salah satu bagian dari upaya pengentasan kemiskinan bagi para petani tanaman pangan.

Hasil penelitian Noviansyah (2018) Nilai rata-rata $\mathrm{R} / \mathrm{C}$ ratio usahatani padi Teknologi Hazton di Desa Peniraman, Kecamatan Sungai Pinyuh, Kabupaten Mempawah adalah sebesar 2,69. Hal ini mengindikasikan bahwa setiap tambahan biaya yang dikeluarkan oleh kegiatan usahatani tersebut akan menghasilkan tambahan penerimaan yang lebih besar dibandingkan tambahan biaya yang dikeluarkan. Dengan demikian, dapat disimpulkan bahwa kegiatan usahatani tersebut merupakan suatu kegiatan usahatani yang layak dan menguntungkan. (2) Variabel jumlah bibit dan pengalaman bertani berpengaruh signifikan terhadap tingkat produksi padi, sedangkan variabel luas lahan dan tingkat pendidikan petani berpengaruh tidak signifikan terhadap tingkat produksi padi usahatani Teknologi Hazton.

Signifikannya jumlah bibit terhadap produksi membuktikan bahwa Teknologi Hazton merupakan suatu metode pertanian padi yang bertujuan meningkatkan produksi padi dengan jalan optimalisasi fungsi lahan dengan cara penggunaan jumlah bibit per lubang tanam yang lebih banyak, sedangkan tidak signifikannya pengaruh luas lahan terhadap produksi padi mengindikasikan bahwa metode pertanian ini tidak menjadikan penambahan luas lahan sebagai kriteria utamanya. Di samping itu, Teknologi Hazton merupakan metode pertanian yang 
tidak jauh berbeda dengan metode pertanian yang selama ini yang diaplikasikan oleh petani. Hal ini terbukti dengan signifikannya variabel pengalaman bertani terhadap produksi padi. Karena metode pertanian ini tidak jauh berbeda dengan metode pertanian yang selama ini diterapkan petani juga menyebabkan petani tidak terlalu mengalami kesulitan dalam mempelajari petunjuk teknis untuk mengadopsi metode pertanian ini, sehingga tingkat pendidikan berpengaruh tidak signifikan terhadap produksi padi. (Noviansyah, 2018).

Hasil penelitian Novanda (2019), bahwa Modal usahatani pada sebagian besar petani merupakan masalah, maka bantuan kredit dengan bunga rendah sangat diperlukan oleh petani. Pada umumnya petani meminjam uang tujuan utamanya adalah untukmodal usaha tani, walaupun kadangkadang langsung meminjam bentuk saprodi. Kemudahan akan akses pembiayaan dapat meningkatkan intensi kewirausahaan petani. Sehingga akses akan pembiayaan sangat diperlukan. Keberhasilan usahatani yang dilaksanakan tidak akan terlepas dari peran kelembagaan agribisnis. Berdasarkan hasil analisis didapatkan akses pembiayaan pertanian memilik pengaruh signifikan terhadap kewirausahaan petani. Nilai odds ratio pembiayaan sebesar 1,85 berarti bahwa kewirausahaan sangat ditentukan oleh kondisi kelembagaan sebesar 1,85 kali. Hal tersebut menunjukkan bahwa usahatani padi Hazton sangat membutuhkan pembiayaan pertanian.

\section{TUJUAN PENELITIAN}

Penelitian ini bertujuan untuk menganalisis hubungan karakteristik sosial ekonomi petani dengan tingkat adopsi inovasi sistem tanam hazton, menganalisis sikap petani terhadap usahatani padi sawah sistem tanam hazton.

\section{BAHAN DAN METODE}

\section{Waktu dan Tempat Penelitian}

Penelitian ini dilaksanakan di Desa Malalin Kabupaten Enrekang selama kurang lebih 4 bulan, yakni dari bulan Januari 2019 hingga Mei 2019.

\section{Metode Penentuan Sampel}

Jumlah sampel pada penelitian ini adalah 26 orang petani yang dipilih secara systematic sampling dengan pertimbangan peneliti memilihi petani yang memiliki luas lahan 0,5- 1 ha; tingkat produksi padi minimal 4 ton/ha; petani yang sedang dalam masa pembinaan penyuluh dan aktif mengikuti pertemuan.

\section{Analisis dan Interpretasi Data}

Metode analisis data adalah Korelasi Rank Spearman, analisis pendapatan, teknik penskalaan likert dan deskriptif. Jawaban setiap item instrumen dalam kuesioner yang menggunakan skala likert mempunyai gradasi dari sangat positif sampai sangat negatif yang dapat berupa kata atau frasa sebagai ekspresi sikap. Berikut tabel penilaian jawaban yang akan digunakan oleh peneliti.

Tabel 1. Skor Jawaban

\begin{tabular}{lc}
\hline \multicolumn{1}{c}{ Jawaban } & Nilai \\
\hline Selalu & 5 \\
Sering & 4 \\
Kadang-Kadang & 3 \\
Jarang & 2 \\
Tidak Pernah & 1 \\
\hline
\end{tabular}


Menurut Sugiyono (2013) kriteria intepretasi skor berdasarkan jawaban responden dapat ditentukan sebagai berikut, "skor maksimum setiap kuesioner adalah 5 dan skor minimum adalah 1, atau berkisar antara $20 \%$ sampai $100 \%$ maka jarak antara skor yang berdekatan adalah 16\% ((100\% - 20\%)/5)." Sehingga dapat diperoleh kriteria sebagai berikut:

Kategori

Tabel 2. Interpretasi Skor Hasil

\begin{tabular}{lc}
\hline Presentase & Interpretasi \\
\hline $20 \%-35,99 \%$ & Tidak Baik / Tidak Efektif \\
$36 \%-51,99 \%$ & Kurang Baik / Kurang Efektif \\
$52 \%-67,99 \%$ & Cukup Baik / Cukup Efektif \\
$68 \%-83,99 \%$ & Baik / Efektif \\
$84 \%-100 \%$ & Sangat Baik / Sangat Efektif \\
\hline
\end{tabular}

Sumber: data yang diolah

Interpretasi skor diperoleh dengan cara membandingkan skor item yang diperoleh berdasarkan jawaban responden dengan skor tertinggi jawaban kemudian dikalikan 100\%.

Korelasi Rank Sperman (rs).

Menurut Siegel (1994) rumus

Korelasi Rank Sperman sebagai

berikut :

$$
R s \square 1 \square \frac{n \square 1^{6} \square i^{2}}{N^{3} \square N}
$$

Dimana :

Rs : Koefisien korelasi rank

Spearman

$\mathrm{N} \quad$ : Jumlahresponden

di : Selisih atau rangking dari

variable pengamatan

Untuk menguji tingkat signifikansi

rank sperman (rs) digunakan uji t student karena sampel yang diambil lebih dari 10 $(\mathrm{N}>10)$ dengan rumus sebagai berikut : $\mathrm{t}=\mathrm{rs}$

$$
\sqrt{\frac{N-2}{1-r s^{2}}}
$$

Kriteria uji:

1. Apabila $t$ hitung $\geq t$ tabel, $(\alpha=0,05)$ maka Ho ditolak, berarti ada hubungan yang nyata antara karakterisitk sosial ekonomi dengan tingkat adopsi petani dalam penerapan sistem tanam hazton di Desa Malalin

2. Apabila $t_{\text {hitung }}<t$ tabel, $(\alpha=0,05)$ maka Ho diterima, berarti tidak ada hubungan nyata antara karakteristik sosial ekonomi dengan tingkat adopsi petani dalam penerapan sistem tanam hazton di Desa Malalin.

\section{HASIL DAN PEMBAHASAN}

\section{Umur Responden}

Umur Responden Salah satu faktor yang mempengaruhi aktivitas seseorang dalam melakukan suatu kegiatan atau dalam mengelola suatu bidang usaha adalah usia. Umumnya seseorang yang yang masih berusia mudah dan sehat, memiliki kemampuan fisik yang lebih kuat bila dibandingkan dengan berusia tua. Seseorang yang masih berusia mudah akan lebih cepat menerima hal-hal yang baru dan berani mengambil resiko serta dinamis. Sedangkan seseorang yang berusia relatif tua mempunyai kapasitas yang lebih matang dan memiliki banyak pengalaman dalam mengolah usahanya sehingga cenderung berhati-hati bertindak dan biasanya bersifat tradisional, walaupun fisiknya berkurang. Untuk lebih jelasnya kelompok usia petani responden dapat dilihat pada Tabel 3.

Tabel 3 Rata-rata tingkat golongan umur petani responden di Desa Malalin Kabupaten Enrekang

\begin{tabular}{cccr}
\hline No & $\begin{array}{c}\text { Golongan } \\
\text { Umur (Tahun) }\end{array}$ & $\begin{array}{c}\text { Jumlah } \\
\text { (Orang) }\end{array}$ & $\begin{array}{c}\text { Persentase } \\
(\%)\end{array}$ \\
\hline 1 & $28-37$ & 9 & 35,00 \\
2 & $38-47$ & 10 & 38,00 \\
3 & $48-57$ & 6 & 23,00 \\
4 & $58-67$ & 1 & 4,00 \\
\hline & Jumlah & 26 & 100,00 \\
\hline
\end{tabular}

Sumber : Data Primer Setelah Diolah Tahun 2019. 
Tabel 3 menunjukkan bahwa dari jumlah responden yang 26 petani padi yang dominan tingkat umur 38-47 tahun dengan jumlah responden 10 orang dengan tingkat persentase (38\%). Hal ini menunjukkan bahwa tingkat umur yang produktif berada pada tingkat umur 38-47 tahun dengan demikian dapat digambarkan bahwa golongan umur petani di Desa Malalin Kecamatan Cendana Kabupaten Enrekang tidaklah menjadi hambatan dalam pengembangan usahatani padi sawah di masa yang akan datang termasuk dalam mengadopsi sistem tanam hazton. Petani padi di Desa Malalin yang tergolong cepat dan respon terhadap adopsi inovasi sistem tanam hazton juga berada di kelompok usia produktif. Hal ini sesuai dengan hasil penelitian Wangke \&Suzana (2016) Umur menjadi salah satu aspek penting dalam melakukan usahatani. Kemampuan menyerap teknologi dan adopsi inovasi sangat berhubungan dengan umur dari petani. Semakin muda umur petani, maka akan semakin mudah petani untuk menyerap teknologi inovasi pertanian.

\section{Tingkat Pendidikan}

Tingkat pendidikan petani baik formal maupun non formal akan mempengaruhi cara berpikir yang diterapkan pada usahataninya. Menurut Suratiyah (2015), pendidikan terhadap petani akan membuka cakrawala pemikiran petani dan menambah keterampilan. Soekartawi (2013) menyatakan bahwa mereka yang berpendidikan tinggi lebih termotivasi dan relatif lebih cepat dalam melaksanakan suatu inovasi. Dengan kemampuannya ini mereka dapat menerapkan segala sesuatu yang telah diperoleh dalam usahanya dengan lebih baik. Mereka yang berpendidikan lebih tinggi lebih mudah terdorong untuk menguasai dan menerapkan teknologi yang pada akhirnya juga turut berperan dalam peningkatan efisiensi dan produksi padi.
Tabel 4. Tingkat pendidikan petani responden di Desa Malalin Kabupaten Enrekang

\begin{tabular}{|c|c|c|c|}
\hline No & $\begin{array}{c}\text { Tingkat } \\
\text { Pendidikan }\end{array}$ & $\begin{array}{l}\text { Jumlah } \\
\text { (Orang) }\end{array}$ & $\begin{array}{c}\text { Persentase } \\
(\%)\end{array}$ \\
\hline 1 & TS & 5 & 19,00 \\
\hline 2 & SD & 12 & 46,00 \\
\hline 3 & SLTP & 4 & 15,00 \\
\hline 4 & SLTA & 3 & 12,00 \\
\hline 5 & S1 & 2 & 8,00 \\
\hline \multicolumn{2}{|c|}{ Jumlah } & 26 & 100,00 \\
\hline
\end{tabular}

Tabel 4 terlihat bahwa tingkat pendidikan petani responden di Desa Malalin Kabupaten Enrekang masih sangat rendah. Ini menunjukkan bahwa dilihat dari tingkat pendidikan petani responden yang dominan adalah Sekolah Dasar sebanyak 12 orang (46\%), Tidak sekolah sebanyak 5 orang (19\%), Sedangkan yang menempuh tingkat pendidikan yang tinggi seperti SMP, SMA, dan S1 sangatlah sedikit, hal ini menunjukkan bahwa tingkat pendidikan yang ditempuh oleh petani responden masih sangat rendah. Hal ini sesuai dengan hasil penelitian Burhansyah (2014) bahwa Rendahnya tingkat pendidikan petani menjadi salah satu proble yang harus dipikirkan. Karena adopsi inovasi hazton akan lebih maksimal apabila tingkatpendidikan petani jauh lebih tinggi denga keterampilan mereka dalam melakukan budiaya padi. Tingkat pendidikan sangat berpengaruh terhadap kemampuan menyerap teknologi inovasi.

Tabel 5. Jumlah tanggungan keluarga responden petani di Desa Malalin Kabupaten Enrekang

\begin{tabular}{|c|c|c|c|}
\hline \multicolumn{4}{|c|}{ Jumlah } \\
\hline No & $\begin{array}{c}\text { Tanggungan } \\
\text { (Orang) }\end{array}$ & $\begin{array}{l}\text { Jumlah } \\
\text { (Orang) }\end{array}$ & $\begin{array}{c}\text { Persentase } \\
(\%)\end{array}$ \\
\hline 1 & $1-3$ & 7 & 27,00 \\
\hline 2 & $4-6$ & 16 & 62,00 \\
\hline 3 & $7-9$ & 3 & 11,00 \\
\hline & Jumlah & 26 & 100,00 \\
\hline
\end{tabular}


Tabel 5 menunjukkan bahwa jumlah tanggungan keluarga responden yang terbanyak adalah petani tingkat tanggungan 4-6 orang yaitu sebanyak 16 orang dengan persentase (62\%), sedangkan jumlah responden yang memiliki tanggungan keluarga yang lebih rendah dar 7-9 orang hanya 3 orang responden atau (11\%).Keadaan demikian memberikan indikasi bahwa petani responden rata-rata memiliki tanggungan keluarga yang tidak terlalu besar sehingga tidak merupakan suatu hambatan dalam hal pengembangan usahatani padi sawah.

Tabel 6. Luas lahan usahatani padi sawah di Desa Malalin Kabupaten Enrekang

\begin{tabular}{cccr}
\hline No & $\begin{array}{c}\text { Luas } \\
\text { Lahan } \\
(\mathrm{Ha})\end{array}$ & $\begin{array}{c}\text { Jumlah } \\
\text { (Orang) }\end{array}$ & $\begin{array}{c}\text { Persentase } \\
(\%)\end{array}$ \\
\hline 1 & $0,05-0,19$ & 9 & 35,00 \\
2 & $0,20-0,34$ & 14 & 54,00 \\
3 & $0,35-0,49$ & 2 & 8,00 \\
4 & $0,50-0,64$ & 1 & 4,00 \\
\hline & Jumlah & 26 & 100,00 \\
\hline
\end{tabular}

Sumber : Data Primer Setelah Diolah Tahun 2019.

Tabel 6 menunjukkan bahwarata rata petani responden relatif kecil, dimana petani responden memiliki lahan yang terbanyak adalah 0,20-0,34 $\mathrm{Ha}$ dengan jumlah responden yaitu 14 orang persentasenya (54\%), sedangkan yang memiliki luas lahan yang paling sedikit adalah 0,50-0,64 $\mathrm{Ha}$ dengan jumlah respondennya sebanyak 1 orang persentasenya (4\%). Petani yang memiliki lahan yang luas akan memungkinkan tingginya jumlah produksi yang akan diterima.

Tabel 7. Pengalaman berusahatani padi sawah di Desa Malalin Kecamatan Cendana Kabupaten Enrekang

\begin{tabular}{cccc}
\hline No & $\begin{array}{c}\text { Pengalaman } \\
\text { Berusahatani } \\
(\text { Thn) }\end{array}$ & $\begin{array}{c}\text { Jumlah } \\
\text { (Orang) }\end{array}$ & $\begin{array}{c}\text { Persentase } \\
(\%)\end{array}$ \\
\hline 1 & $5-13$ & 4 & 16,00 \\
2 & $14-22$ & 17 & 65,00
\end{tabular}

\begin{tabular}{cccr}
3 & $23-31$ & 5 & 19,00 \\
\hline \multirow{2}{*}{ Sumber } & Jumlah & 26 & 100,00 \\
& $\begin{array}{l}\text { Data Primer } \\
\text { Tahun 2019. }\end{array}$ & Setelah & Diolah \\
& &
\end{tabular}

Tabel 7 menunjukkan bahwa pengalaman berusahatani padi dari 26 orang petani responden yaitu yang mengalami pengalaman bertani paling banyak di dominasi oleh pengalaman14-22 tahun sebanyak 17 orang dengan persentase (65\%) dan $23-30$ sebanyak 5 orang (20\%), sedangkan yang terkecil adalah petani responden dengan pengalaman kurang atau sama dengan 5-13 tahun sebanyak 4 orang $(15 \%)$.

Tabel 8. Hubungan Karakteristik Sosial Ekonomi Petani dengan Tingkat Adopsi Inovasi Sistem Tanam Hazton.

\begin{tabular}{llll}
\hline $\begin{array}{l}\text { Karakteristik } \\
\text { SosialEkonomi }\end{array}$ & Rs & $\begin{array}{c}\mathrm{T} \\
\text { hitung }\end{array}$ & Ket \\
\hline Luas Lahan $(\mathrm{X} 1)$ & 0,410 & 3,423 & $\mathrm{SS}$ \\
\hline Pendidikan (X2) & 0,065 & 0,496 & $\mathrm{NS}$ \\
\hline $\begin{array}{l}\text { Tanggungan } \\
\text { Keluarga(X3) }\end{array}$ & 0,235 & 1,775 & $\mathrm{NS}$ \\
\hline Umur(X4) & $-1,270$ & 1,136 & $\mathrm{NS}$ \\
\hline $\begin{array}{l}\text { Pengalaman } \\
\text { Berusahatani(X5) }\end{array}$ & $-1,204$ & 1,587 & $\mathrm{NS}$ \\
\hline Pendapatan (X6) & 0,275 & 2,146 & $\mathrm{~S}$ \\
\hline
\end{tabular}

Tabel 8 menunjukkan bahwa nilai koefisien korelasi antara luas lahan dengan tingkat adopsi inovasi sistem tanam hazton adalah 0,410 dengan thitung sebesar 3,423 yang lebih besar dari $t_{\text {tabel }}$ yaitu sebesar 2,000 pada taraf kepercayaan $95 \%$. Hal ini menunjukkan bahwa luas lahan mempunyai hubungan yang sangat signifikan dengan tingkat adopsi inovasi tanam hazton . Berarti semakin luas lahan petani maka semakin tinggi tingkat adopsi inovasi sistem tanam hazton. Petani yang memiliki lahan yang luas memiliki harapan untuk mendapatkan keuntungan yang besar sekalipun resiko mengalami kegagalan besar pula. Nilai Rs positif menunjukkan terdapat hubungan yang searah antara luas lahan dengan tingkat adopsi inovasi sistem tanam hazton. Semakin tinggi luas lahan petani semakin 
tinggi pula tingkat adopsi inovasi sistem tanam hazton.

Nilai koefisien korelasi antara pendidikan formal dengan tingkat adopsi inovasi sistem tanam hazton adalah 0,065 dengan $t_{\text {hitung }}$ sebesar 0,496 yang lebih kecil dari tabel yaitu sebesar 2,000 pada taraf kepercayaan 95\%. Hal ini menunjukkan bahwa pendidikan formal mempunyai hubungan yang tidak signifikan dengan tingkat adopsi petani sistem tanam hazton. Hubungan yang tidak signifikan ini disebabkan karena rata-rata tingkat pendidikan responden hanya sampai SD. Minat responden dalam mengetahui hal-hal baru juga relatif rendah. massa yang ada yaitu buletin minat responden untuk membaca juga kurang.Nilai Rs positif menunjukkan terdapat hubungan yang searah antara pendidikan dengan tingkat adopsi inovasi sistem tanam hazton. Semakin tinggi tingkat pendidikan petani semakin tinggi pula tingkat adopsi inovasi sistem tanam hazton.

Nilai koefisien korelasi antara tanggungan keluarga dengan tingkat adopsi inovasi sistem tanam hazton adalah 0,235 dengan $t_{\text {hitung }}$ sebesar 1,775 yang lebih kecil dari tabel yaitu sebesar 2,000 pada taraf kepercayaan 95\%. Jumlah keluarga menunjukan jumlah orang anggota yang tinggal dalam suatu rumah tangga. Hal ini menunjukan bahwa jumlah keluarga mempengaruhi ekonomi keluarga responden. Semakin besar jumlah anggota keluarga responden maka kebutuhan keluarga juga akan semakin meningkat sehingga biaya hidup yang dikeluarkan juga akan semakin besar. Meskipun demikian, petani di Desa Malalin sebagian besar juga budidaya jagung selain padi, sehingga juga menjadi salah satu alasan sebagian dari mereka belum mau beralih sistem tanam hazton.Nilai Rs positif menunjukkan terdapat hubungan yang searah antara jumlah tanggungan keluarga dengan tingkat adopsi inovasi sistem tanam hazton. Semakin tinggi jumlah tanggungan keluarga petani semakin tinggi pula tingkat adopsi inovasi sistem tanam hazton.

Nilai koefisien korelasi antara umur dengan tingkat adopsi inovasi sistem tanam hazton adalah $-1,270$ dengan dengan thitung sebesar 1,136 yang lebih besar dari tabel yaitu sebesar 2,000 pada taraf kepercayaan 95\%. Hal ini menunjukkan bahwa umur. mempunyai hubungan yang non signifikan dengan tingkat adopsi inovasi tanam hazton. Hal ini dapat dilihat dari umur responden petani antara 38-47 tahun yang tergolong produktif. Umur yang produktif akan lebih mudah dan cepat dalam menerima inovasi. Umur yang produktif lebih bersemangat dalam bekerja dan melakukan pembaharuan.Tidak signifikan pengaruhnya disebabkan sebagian responden petani juga sudah berusia tidak produktif lagi yakni rentan 57-67 sebanyak 7 orang. Nilai Rs negatif menunjukkan terdapat hubungan yang tidak searah antara umur dengan tingkat adopsi inovasi sistem tanam hazton. Semakin tinggi umur petani semakin rendah tingkat adopsi inovasi sistem tanam hazton.

Nilai koefisien korelasi antara pengalaman berusahatani dengan tingkat adopsi inovasi sistem tanam hazton adalah $-1,204$ dengan $t_{\text {hitung }}$ sebesar 1,587 yang lebih kecil dari $t_{\text {tabel }}$ yaitu sebesar 2,000 pada taraf kepercayaan 95\%. Hal ini menunjukkan bahwa pengalaman berusahatani mempunyai hubungan yang tidak signifikan dengan tingkat adopsi petani sistem tanam hazton. Data responden petani menunjukkan pengalaman berusahatani 14-22 tahun secara konvensional berdasarkan kebiasaan turun temurun. Faktor pengalaman yang tidak signifikan terhadap adopsi sistem tanam hazton juga berkaitan dengan aspek pengetahuan petani dalam memahami sistem tanam hazton.Nilai Rs negatif menunjukkan terdapat hubungan yang tidak searah antara pengalaman berusahatani dengan tingkat adopsi inovasi sistem tanam hazton. Semakin tinggi pengalaman berusahatani petani semakin rendah tingkat adopsi inovasi sistem tanam hazton.

Nilai koefisien korelasi antara pendapatan dengan tingkat adopsi inovasi sistem tanam hazton adalah 0,275 dengan $t_{\text {hitung }}$ sebesar 2,146 yang lebih besar dari $t_{\text {tabel }}$ yaitu sebesar 2,000 pada taraf 
kepercayaan 95\%. Hal ini menunjukkan bahwa pendapatan mempunyai hubungan yang signifikan dengan tingkat adopsi inovasi sistem tanam hazton, yang berarti semakin tinggi pendapatan petani maka tingkat adopsi petani juga akan semakin tinggi. Hal ini terjadi karena responden yang memiliki tingkat pendapatan yang tinggi akan dapat melakukan tindakan apapun untuk keberhasilan usahataninya, walaupun dalam penyiapan bibit dan pupuk mendapatkan bantuan dari pemerintah. Nilai Rs positif menunjukkan terdapat hubungan yang searah antara pendapatan dengan tingkat adopsi inovasi sistem tanam hazton. Semakin tinggi pendapatan semakin tinggi pula tingkat adopsi inovasi sistem tanam hazton.

Untuk mengetahui sikap petani terhadap usahatani padi sawah dengan sistem tanam Hazton dibuat 30 pernyataan, yang terdiri dari 15 pernyataan positif dan 15 pernyataan negatif. Sikap petani terhadap usahatani padi sawah dengan sistem tanam Hazton adalah sebagai berikut.

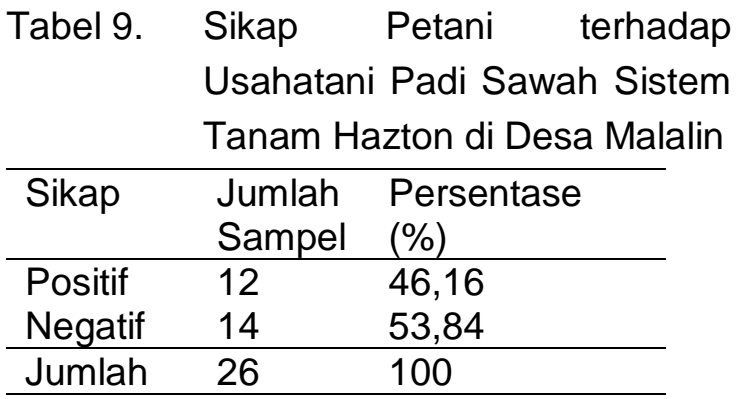

Dari Tabel 9 diketahui bahwa petani sampel sebanyak 46,16\% bersikap positif dan 53,84\% bersikap negatif terhadap penerapan usahatani padi sawah dengan sistem tanam Hazton. Adanya persentasi sikap petani sebanyak 53,84\% yang bersikap negatif membuktikan bahwa adanya masih keragu-raguan petani untuk bersikap tegas dalam hal penerapan sistem tanam hazton pada usahataninya. Hal ini dikarenakan petani belum terbiasa dengan sistem tanam yang baru dikenalkan tahun 2016 oleh penyuluh melalui SLPTT, kesulitan melakukan penanaman yang hal ini dikarenakan Kebanyakan orang berpendapat, bibit tua tidak menghasilkan bulir padi yang banyak. Namun, semakin tua bibit padi, justru semakin tahan terhadap penyakit. Dari hasil penelitian, didapati juga semakin padat bibit padi yang dimasukkan dalam satu lubang, akan semakin banyak menghasilkan padi berkualitas dan kuat berkompetisi. Salah satunya, meminimalisir hama keong yang hanya suka pada padi muda. Selain itu modal tanam akan bertambah karena menggunakan bibit 20-30 bibit per lubang tanam, yang biasanya modal tanam per hektar 5 juta naik menjadi 7 juta per hektar. Sebagaimana hasil penelitian sebelumnya bahwa Teknologi Hazton merupakan metode pertanian yang tidak jauh berbeda dengan metode pertanian lainnya kecuali dalam hal penggunaan bibit yang lebih banyak per lubang tanam. Hal-hal lain seperti jenis bibit, jenis pupuk, jenis pestisida, kegiatan persiapan lahan, penyemaian, penanaman, pemupukan, penyiangan rumput, aplikasi pestisida, pemanenan hingga kegiatan pasca panen adalah sama seperti yang selama ini dilakukan oleh petani dengan metode pertanian padi lainnya. Pengalaman petani dalam mengatasi berbagai kendala dalam kegiatan usahataninya tetap diperlukan dalam mengadopsi metode pertanian baru ini. Oleh karena itu, signifikannya pengaruh variabel pengalaman bertani terhadap tingkat produksi padi Teknologi Hazton merupakan hal yang memang sudah sepatutnya terjadi. (Noviansyah, 2018).

\section{KESIMPULAN}

Hasil penelitian menunjukkan karakteristik sosial ekonomi petani yang berpengaruh signifikan terhadap tingkat adopsi inovasi sistem tanam hazton adalah luas lahandan pendapatan. Sedangkan karakteristik sosial ekonomi petani yang berpengaruh non signifikan terhadap tingkat adopsi inovasi sistem tanam hazton adalah lamanya berusahatani, umur, pendidikan dan jumlah tanggungan keluarga. Luas lahan, Pendidikan, jumlah tanggungan keluarga dan pendapatan bernilai positif $(R s+)$ dan memiliki hubungan yang searah dengan tingkat 
adopsi inovasi sistem tanam hazton. Sedangkan umur dan pengalaman berusahatani bernilai negatif (Rs -) dan memiliki hubungan yang tidak searah dengan adopsi inovasi sistem tanam hazton.

Petani sampel sebanyak $53,84 \%$ bersikap negatif dan $46,16 \%$ bersikap positif terhadap penerapan usahatani padi sawah dengan sistem tanam hazton. sikap petani terhadap adopsi inovasi belum seluruhnya menerima dilihat dari hasil presentase penilaian persepsi petani. Namun dari hasil perhitungan pendapatan usahatani petani padi yang menggunakan sistem tanam hazton menunjukkan keuntungan yang didapatkan petani dibanding menggunakan sistem tradisional. Diharapkan kedepannya dengan tingkat keuntungan yang didapatkan petani yang menggunakan sistem tanam hazton dapat menjadi motivasi petani tradisional untuk mengadopsi sistem tanam hazton.

\section{DAFTAR PUSTAKA}

Ekaria., Munawir Muhammad. 2019. Analisis Usahatani Padi Sawah dengan Metode Hazton di Desa Lolori Kabupaten Halmahera Barat. "Jurnal Agribisnis Perikanan- AGRIKAN STIP Wunaraha, Vol. 12 (2): 197-202
Novanda, Ridha R. 2019. Pengaruh Kelembagaan, Pembiayaan, dan Kemandirian terhadap Kewirausahaan Petani Padi metode Hazton di Kabupaten Menpawah Kalimantan Barat. "Journal of Agricultural Sosioeconomics and Business, Vol. 2(2).

Noviansyah, Y.,Nurul Bariyah. 2018. Analisis Usahatani Padi Teknologi Hazton di Provinsi Kalimantan Barat (Studi Kasus : Desa Peniraman, Kecamatan Sungai Pinyuh, Kabupaten Menpawah. " Jurnal Ekonomi Bisnis dan Kewirausahaan, Vol. 7 (1) : 1-19.

Panjaitan, A, Hasyim, $\mathrm{H}$, dan Emalisa. 2013. Hubungan Karakteristik Sosial Ekonomi Petani dengan Pendapatan USAhatani Padi Sawah Sistem Tanam Legowo 4:1 (Studi Kasus : Desa Sei Buluh, Kecamatan Teluk Mengkudu, Kabupaten Serdang Bedagai)." Journal of Agriculture and Agribusiness Socioeconomics, Vol. 2(3): 1-14

Soekartawi. 2003. Analisis Usahatani. UI Press. Jakarta.

Sugiyono. 2013. Statistika untuk Penelitian. CV. Alfabeta. Bandung

Suratiyah, K. 2005. Ilmu Usahatani. Penebar Swadaya. Jakarta. 